\title{
Rebuilding the Pre-hispanic Religiosity in an Urban Area: the Case of the Urban Sikus Bands in Buenos Aires
}

\author{
Alejandra Vega \\ National University of the Arts, Argentina
}

Copyright $\bigcirc 2016$ by authors, all rights reserved. Authors agree that this article remains permanently open access under the terms of the Creative Commons Attribution License 4.0 International License

\begin{abstract}
The emergence of the first urban sikus bands in the late $19^{\text {th }}$ Century was closely related to the performance of such ensembles in traditional Andean Catholic religious celebrations. At present, the relationship between Catholic devotion and these bands is preserved among the small populations of the Andean region of Bolivia, Peru, northwestern Argentina and northern Chile. By contrast, in the context of the current processes of re-ethnicization, the sikus bands in large cities have not only lost the strong bonds with the Church, questioning its role during the Spanish conquest, but have adapted and recreated pre-Hispanic beliefs and appropriated Eastern notions and ideas of the sacred as reformulated and disseminated by New-Age movements. I will explore and analyze the contrasting narratives that dispute "religious authenticity" among the members of sikus bands in contemporary Buenos Aires. This article is based on data gathered in my ethnographic fieldwork conducted in several phases between 2001 and 2012 in the Metropolitan Area of Buenos Aires, through participant observation in different sikus bands and from interviews with key informants.
\end{abstract}

Keywords Sikus Bands, Religiosity, Re-ethnization, Buenos Aires

\section{Introduction}

During the 1990s, a great influx of migrants of indigenous descent came from Bolivia and Peru and settled in the Buenos Aires metropolitan area. These communities brought religious practices that belong to Catholic tradition - the religion to which the vast majority of people from these countries belong- that had long disappeared from the city. The most important celebration for the Andean region migrants is a big parade to venerate Our Lady of Copacabana, patron saint of Bolivia.

The Andean panpipe -or siku- ensembles are among the many dance and music groups that take part in this parade. This native instrument has also become a symbol of indigenous culture, although it has been largely used to worship Catholic icons brought by the Spanish conquest. However, due to the growing influence of the indigenous rights groups and their criticisms of Catholicism, and to the exposure of different religiosities in the urban sectors as well, performing at this fiesta (the most important special event for the migrant community) has lost its relevance for the sikus bands.

As their commitment to the indigenous rights cause grew, the sikus bands' members developed different strategies to cope with the contradiction between their Christian religious heritage - which is very strong in the Andean region where they came from - and their native pride ideology. These processes include both the re-creation of religious practices of different levels of historical bases, aiming to rebuild their native identity, and the appropriation of influential ideas and practices that come from the New Age realm, but are considered or claimed to be natives. Furthermore, their new religiosities foster ideological and political support from anti-system groups form urban sectors. All these actions are part of a bigger process that is currently taking place in Latin America, through which the oppressed indigenous groups have been trying to strengthen their native identity, culture and knowledge, as well as struggling for their political rights. Many of these changes are displayed at the religious parade; others are evidenced in the growing importance of other religious and secular events organized by the community of migrants or the sikus bands themselves.

Based on data gathered among different sikus bands from the Buenos Aires metropolitan area between 2001 and 2012 through participant observation and extensive, open and in-depth interviews, I will describe and analyze the religious/spiritual discourses and practices that the members of the bands develop to adapt their belief systems to a new urban context, where the relevance of indigenous rights activism has increased since the return of the democracy in 1983. In turn, all these changes contribute to the emergence of new indigenous subjectivities that the social actors describe as a recovery of their true identity. 


\section{The siku, a Living Symbol of the Ancient Native Culture}

The Indianista ${ }^{1}$ movements from the Andean regions of Peru, Bolivia, northern Chile and northwest Argentina have two powerful reasons to have chosen the Andean Pan flute called siku as a symbol of resistance and a means for rebuilding their indigenous identity in urban areas. The first reason is the historical provenance of the instrument in the Andean region. It dates from thousands of years ago; indeed, Peruvian authors such as Bolaños [1] claim that the first Andean Pan flute or panpipe appeared almost 7000 years ago $^{2}$. The second reason is the communal implications of the instrument itself and the way it is played. As described below, both its structure and traditional performance modes require forms of collaboration; here the social actors find analogies to the lifestyle that they attribute to their communities in the pre-Hispanic past, and which they propose as an alternative to Western economic and social models.

The siku -a term taken from the Aymara- or zampoña -in Spanish- is an aerophone consisting of several closed-end cane pipes of different lengths tied in a row; according to the Hornbostel-Sachs classificatory system, its code is 421.112.21. These canes, usually made of local bamboo, are blown directly across their rim. The siku is traditionally played in large ensembles, which are comprised of several pairs of players, and usually include membranophones such as the bombo or the huancara, or even snare drums, depending on their places of origin. It is also used in small bands that play what Carlos Vega [3] called folklore de proyección (folk-inspired music) in urban areas. The instrument was popularized by these small groups, in which it is usually combined with other instruments such as guitar, charango (a small local string instrument) and quena (a traditional edge-blown vertical flute without duct). In this way it became known outside of the Andean rural areas. In the 1970s and '80s, Chilean musicians from the movement Nueva Canción $^{3}$ started to gain listeners in Argentina, and influenced local folk music artists; this led to the increased knowledge and use of the siku in Argentine cities.

Whereas in these small criollo groups the siku is usually

1 I will use the emic category indianista (and Indianism) to refer to the indigenous liberation movements of the region. I decided not to use the term "indigenismo" for the indigenous-pride ideology, due to the fact that the latter was coined by local artists and intellectuals that aimed to reshape national identities in the late $19^{\text {th }}$ century by adding certain prestigious features of the ancient indigenous cultures from the highlands, considered as high cultures.

2 In 2009, Mansilla Vázquez [2] determined the age of Fréderic Engels' archeological finds at the Chilca site. Mansilla Vázquez did not find the panpipe described by Bolaños: there was only an approximately 5750 -year-old quena. Bolaños [1] took the age attributed by Silva in 1978 . This date was taken by researchers and then popularized, contributing to enlargement of the antiquity of the Andean cultures, a core value for the indianistas for defining their ancient culture or cultura ancestral.

3 In Latin America, the movement Nueva Canción (New song) emerged in the 60 's, seeking to conjugate musical aesthetics from regional folklore with an antiimperialist discourse. At that moment, Latin American bourgeoisies were experiencing renewal processes, such as the Cuban revolution in 1959. During the 1970s, a period of dictatorships, the movement became carrier of political opposition messages, often in the shadows. played by a single musician, in the large traditional sikuris ${ }^{4}$ ensembles two performers play together using a pair of instruments. Each instrument produces only half of the notes that comprise the whole tonal system. Because the scale is divided between the two complementary sets of pipes, the players have to work together in close collaboration in order to achieve a truly autonomous melodic line. A high level of synchrony and mutual understanding must be developed, one that exceeds the basic coordination necessary in every musical ensemble. This performing mode is termed "complementarity" or "bipolarity" -bipolar performing mode- [4]. In Bolivia and Peru, the complementary halves of these pairs are called, respectively, ira (in Aymara, the one who guides), and arka (in Aymara, the one who follows); in Buenos Aires they are designated seis (six) or siete (seven), according to the number of canes that the instrument has. Today, the members of the Indianistas' movements draw an analogy between the complementarity of the performance mode in the sikuris bands and the reciprocity systems of the Andean communities, such as the ayni or the minka [5].

The first Andean panpipes were isolated instruments, which indicate a performance by single individuals. The first iconographic representations of group playing belong to the Nazca (100 AD to 750 AD) and Mochica (100 AD to 800 AD) cultures. Complementary instruments have not been found; therefore, as Uribe Taboada [6] emphasizes, the complementariness cannot be assumed. The first description of bipolar performance was published by Garcilaso de la Vega in his famous chronicles Comentarios Reales de los Incas, in 1609 [7]. In NW Argentina, panpipes made of clay, wood and stone have been found in the Cordillera region from San Juan to the Calchaqui boundaries and in Santiago del Estero's plains [8].

For the Indianistas, the value of the sikus' bands stems from and inheres in the resilience and permanence of modes of social functioning based on complementarity. Such modes were crucial in enabling natives to survive the oppression and plundering that came with the Spanish conquest, and continued in different forms through independence from the Spanish Crown and the emergence and development of the nation-state. Therefore, the importance of sustaining and promoting the creation of these bands lies in the possibilities that they offer not only of keeping their musical heritage alive, but also of putting into practice modes of interaction that replicate traditional reciprocity systems. It is a paradox that the creation of the urban sikus' bands is indebted to traditional Catholic celebrations, which continue to be the most important occasions for siku performance in small towns and rural areas, thereby keeping the tradition alive.

4 Sikuri is the person who plays sikus. I choose the word sikuris for the plural, adding an "s" as in Spanish, due to this is the usual word that the social actors use. 


\section{The Sikus Bands and the Religious Context: Our Lady of Copacabana}

Whereas in the nineteenth and the first half of the twentieth centuries the great majority of migrants into the greater Buenos Aires metropolitan region came from Europe, the last half century has witnessed a growing influx from neighboring South American countries. Nearly half of the recent immigrants to Argentina came from bordering countries [9]. Also, whereas most of the immigrants from previous waves tended to settle in the countryside, the main destinations of these more recent arrivals have been urban centers and their outskirts, especially Buenos Aires [10]. Bolivia and Peru had been major countries of origin of these new migrants since the 1960s, but during the 1990s political developments (in Peru especially), as well as economic incentives, resulted in even greater movement of people from these countries into Argentina. This increase was triggered, notably, by the collapse of the clothing industry in Bolivia [5]; thus, in 1991, 39\% of the 847,697 registered immigrants were of Bolivian origin [9] and their preferred place of settlement was Buenos Aires. Furthermore, since many migrants do not legalize their status (a fact acknowledged even by the interviewed immigrants) these published statistics are almost certainly lower than the actual rate.

The Bolivian and Peruvian immigrants brought with them their own traditional ways of professing their Catholic faith. For example, Buenos Aires started to witness the revival of traditional Catholic parades ${ }^{5}$ of a type that had long before disappeared in the city, in which different fraternities as well as traditional large dance or music groups participate. Sikus bands are among these groups. These kinds of festivities go beyond the religious sphere to impact other modes of social organization. So, in 1972, together with the local priests, Bolivian migrants organized the celebration of Our Lady of Copacabana, the patron saint of Bolivia. This took place in the Barrio Charrúa, one of the neighborhoods settled by Bolivian migrants. From its inception until 2010, the popularity of this festival increased steadily; however, in 2011, many of those who had been actively involved in Charrúa ${ }^{6}$ began to support another celebration located in downtown Buenos Aires. The image used in the Charrúa festivity came from Bolivia. But the original image of Our Lady of Copacabana, sculpted by Tito Yupanqui in 1583, had taken the Peruvian image of Our Lady of Candelaria from Puno as a model. Today, the Fiesta de la Candelaria in Puno attracts the main sikus bands of the region in January.

As a minority group in Argentina, the immigrants have

5 Although these Catholic parades have disappeared in Buenos Aires, they are traditional in many provinces, particularly in the northwestern region of the country.

6 Charrúa is the name of a street of the the popularly known as Barrio Charrúa (Charrúa neighborhood), in Nueva Pompeya, Autonomous City of Buenos Aires. On that street is placed Our Lady of Copacabana chapel- The participants at the celebration in her honour (popularly known as "Fiesta de Charrúa" or just "Charrúa") parade in front of this chapel. suffered discrimination. The Charrúa festival counters this by affirming social identity for the Bolivian and Peruvian migrants from the Andean region, who share a similar cultural heritage. As is generally the case in mestizo Latin America, the religious festival is an occasion that brings together economic, social, aesthetic, and political aspects of group identity. The celebration, which appropriates the public areas surrounding the church, can be defined, using the terminology of Sassone and Hughes [11], as an action of territorial construction shaped by faith ("acción de construcción territorial modelada por la fe"). However, in the context of recent migration, this reenactment of the traditional celebration foregrounds socio-cultural aspects, particularly those related to identity, to the detriment of the religious. The forms of artistic practice staged by the migrants in the context of the recreated festival (costume, dance, music, etc.) are especially valued by the community; this provides a favorable environment for innovation and expression to develop.

The members of the sikus bands are not a homogeneous group. Many migrants come from Bolivia, others come from Peru. They have also lived in Buenos Aires for different amounts of time; some are young Argentines born in Buenos Aires or in the northwest region of Argentina (the majority in Jujuy province), while some are descendants of the immigrants previously mentioned. Some of these descendants have been living in Argentina for a longer time than they lived in their countries of origin. On the other hand, the great majority of the members of other participant groups, such as the so called native or criollo dance groups -among which the caporales and morenadas are prominent- are Bolivians or their descendants, and most citizens of Bolivia are Catholic ${ }^{7}$.

The importance that the "Our Lady of Copacabana" celebration has for the Bolivian community is reflected in the massive participation of these immigrants; it therefore provides a privileged occasion to observe and study changes produced in the area of religion among them and their descendants -specifically the emergence of new religious practices and conceptions-. The presence, the intentional absence, and the semiotic use of their bodies to express a difference from the traditional Catholic inheritance of the sikuris of the Buenos Aires metropolitan area within the sacred space of the procession is not only related to the specific ideological debates about the role of the religion in the conquest of Latin America, but also shows the emergence of new religiosities. Using these strategies, the social actors are able to establish and maintain a critical position vis-à-vis the Catholic Church as well as other institutionalized religions viewed as power groups. They thus re-signify their participation in the celebration as both an affirmation of

7 The NW region of Argentina shows similar characteristics: 91,7\% of people living there defined themselves as Catholics in 2008. The same survey reveals that young people aged under 29 is the group with the biggest percentage of religiously indifferent

citizens.http://www.ceilpiette.gov.ar/areasinv/religion/relproy/1 encrel.pdf 
cohesive native identity and, together with other practices, as an individual experience of spirituality sometimes associated with the Indianista ideology.

Each year prior to the festival, it is usual for the sikus bands to come together and go through a collective decision making process about the mode of participation of each band, as well as about the characteristics of the celebration itself. The debate and discussion brings to light ideas and notions of the sacred that are rarely addressed, and provides a context within which the sikuris are invited to reflect on and talk about their own beliefs. In these contexts, the debates guide the decisions of each band regarding their attendance at the festivity, and their mode of participation. The different strategies of the bands are connected to the processes of re-ethnicization or "identity restoration," as it is termed by the social actors themselves.

\section{The Sikus Bands and Indianism in Buenos Aires}

As stated above, the urban sikus bands in Buenos Aires metropolitan area are usually composed of young people of different origins, with a prevalence of Bolivians and their descendants. Many young Peruvians have joined groups previously founded by Bolivians, while others have created their own bands. There is also a growing number of Argentines that have joined the bands. Their numbers vary depending on the group; many of them were born in Jujuy province, while others are porteños (born in Buenos Aires), who have been attracted mainly for aesthetic reasons. The descendants of Bolivian migrants and Bolivian children that migrated to Argentina at an early age share the influence of the Argentine education system as well as that of their peer groups, where the majority of the children are Argentines. The influence of the Argentine mass media is also stronger in children than in their parents, because they spend a significant part of their free time exposed to it.

The first sikus band of the city was created more than 30 years ago. However, the bands began to multiply in the 1990s due not only to the aforementioned demographic changes, but also to the growing interest in the bands themselves. This interest can be correlated with the growth and increasing relevance of indigenous peoples' movements in Argentina and Latin America. The last decades of the $20^{\text {th }}$ century witnessed key milestones in the struggle of native peoples for rights and recognition. In the case of Argentina this occurred when the ethnic oppression suffered by native communities was brought to light after the return to democracy in 1983. In Bolivia, an extended hike of 34 days called "Marcha por el Territorio y la Dignidad" (Walk for the Territory and Dignity) ended with an indigenous victory in 1990, and was a turning point in the movement that resulted in the election of Evo Morales as the first indigenous president. In 1992, in Mexico, after the Constitution was modified to allow the privatization of communal ejido-land, a rebellion developed among the Lacandon Mayan in Chiapas, which ended in the uprising of the Zapatistas in 1994. Meanwhile, a common stance in Latin America was consolidated in 1992 by the indigenous peoples' movements in order to deconstruct the hegemonic discourse commemorating the arrival of Christopher Columbus to America. In Buenos Aires, a massive demonstration against the Spanish conquest and colonization put the indigenous voices and culture in the center of the public space, and this included their panpipes.

In Buenos Aires, many youngsters who had no special ties or interest to the indigenous music tradition came into contact with the sikus bands during these kinds of demonstrations, and found ideological affinities between Indianism and contra-hegemonic movements. This political convergence increased after the 2001 Argentine economic collapse. In 2010, when the government prepared a luxury mega event to commemorate the bicentennial of the first local government independent of the Spanish Crown, the Indianists and many social movements joined to organize " $\mathrm{El}$ Otro Bicentenario" (the Other Bicentennial) to publicly expose their rejection of a government that had excluded a large segment of the population, especially aboriginal peoples, throughout the history of the independent nation-state, from its consolidation to the present.

In this complex context of re-ethnicization processes, globalization, a secular education system, anticolonialist and antiimperialist discourses, and growing exposure to New Age related contents in the media, the young sikuris have reconfigured their religiosity. The results are diverse, due to the heterogeneity of their experiences and the varying extent of their enculturation in the Catholic faith. However, the response they propose to resolve the contradictions that arise from being affiliated to a religion perceived as instrumental to the oppression, their traditions, and the Indianista ideological influence can be used to present a topography of the religiosity of the Sikus bands of Buenos Aires, as I will do in the following section. This will help us to understand the transformation processes that have been taking place.

\section{Religious Expressions and the Experience of the Sacred among the Sikus Bands}

\subsection{Religious Experience and the Use of the Consecrated Space in Charrúa}

The bands that each year decide to participate in the traditional celebrations are those that were founded by migrants from Bolivia and/or Peru, and whose members are mainly migrants. In these bands, the founders and older members typically come from the same town or region, and attempt to preserve the musical style of their places of origin. They remain in close contact with their native towns, keeping up family ties and continuing to build ritual kinship 
networks; they frequently return for holidays, family celebrations and special events such as weddings, baptisms, the first hair-cutting called rutichico or rutuchicuy, and the like. In some cases, they retain the name of the band to which the founder belonged before moving to Argentina, its repertoire (or most of it), and distinguishing characteristics of its costumes. Such bands are called "bases," and usually add "base Argentina" to the name of the band taken as a model, meaning "based or headquartered in Argentina."

These ensembles take bands of the Andean region as socio-cultural as well as musical models; this includes, of course, religious traditions. Thus, despite the general debates and the issues raised by supporters of indigenous peoples' struggles about the participation of native groups in Catholic celebrations, these bands continue to take part in the fiesta according to the traditional customs. In the immigrants' communities, other practices of Catholic and Spanish origin are preserved, such as the fiesta-cargo systems [12] of pasantes $^{8}$. And despite the significant expense involved in sponsorship, the most committed members of these bands take up the challenge.

Thus, the Peruvian founder of the band Intercontinentales Aymara de Huancané-Base Argentina explains the position of his band: "...we are the Argentine branch of the Intercontinentales Aymara de Huancané. We respect, follow and keep the traditions of the Central [headquarters] in Puno".

His wife, a prominent sikuri and member of the band, added: "In our case, our families are Catholic and we have baptized our sons [...]. We were pasantes of Saint Cecilia, as a group and as a family as well" (C., Intercontinentales Aymaras de Huancané-Base Argentina).

One of the members offered an explanation for the group decision to participate following the traditional style, and therefore declining to confront the multiculturalist discourse that provides support for the indigenous rights movements' claims:

"In our group we respect all the beliefs, so when we parade in Charrúa we must respect the Virgin, although some may not believe. We always say that... and if we were invited by other religions [religious groups] we will be respectful too. We did it when we were invited by a group at Tigre, they had a strange ceremony... they say it is more natural... for us, it didn't make much sense. It was funny, but we remained there".

The ceremonies this informant mentioned are part of new religious expressions critical of Western institutionalized religions. The feeling of strangeness expressed by the informant -and which other members also felt, according to

8 The pasantes, a couple of migrants living in Buenos Aires, sponsor the fiesta -or a great part of it-, being responsible for taking care of the sacred image and the needs of the participants. The pasantes change each year, and count with the collaboration of many participants, particularly founders and directors of fraternities and groups. The cooperation leads to the establishment or the reinforcement of the ritual kinship tie called compadrazgo. their comments- shows their disconnection from the indigenous traditional rites that are alive in rural communities, which the members of the band know well.

In addition to the religious aspect, the festival of Our Lady of Copacabana is extremely important to showcase the quality of the band's performance within the migrant community, where they feel they belong. As a Bolivian informant that has participated in many bands argues: "Everybody goes to Charrúa; that is the place to show our work and our improvements to our fellow countrymen. We have to go, no matter what, to play there, for us, because the fiesta belongs to us."

However, not only the Bolivian or Peruvian bands go to Charrúa; many of the sikus bands whose members are mainly Argentine (or that were founded by Argentines) also participate in the festivity. These bands fall into a second category, which can be called "Argentine bands." They parade in the same traditional way as those described above, despite the fact that the vast majority of the local members, even though they may have been raised in Catholic families, or in what can be broadly defined as a Christian cultural background, do not identify as Catholics. Nevertheless, they also take part in pre-Hispanic/indigenous origin rituals, often celebrated collectively by a group of bands, such as the Inti Raymi $^{9}$, Qhapaj Raymi ${ }^{10}$, or Alasitas ${ }^{11}$. They also participate whenever a chaya ${ }^{12}$ or challa takes place; these rituals, in which alcoholic drink offerings are given to the Pachamama (the native deity Mother Earth) to thank her or ask for her protection, do not have a specific date. The meaning that the Argentines find in all these rituals is, quite simply, to share the experience; they do not consider the parade a religious experience, nor do they think of the Pachamama as a deity, although they value the attitude of respect for nature that they find in indigenous cultures. In some cases, they reinterpret Pachamama rituals to accord with their own need to develop a more respectful and harmonic relationship with the environment. This idea has its roots in ecologist ideology and counter-hegemonic postures, and, in a few cases, in a new form of spirituality which is part of the New Age beliefs [13-14].

On the other hand, the Argentine sikuris, aware of the historic role that the Catholic Church played in Latin America, do not question the participation of any of the

9 Inti is the Quechua word for sun; raimy is the Quechua term for fiesta or celebration. The Inti Raymi or Fiesta of the Sun is celebrated on winter solstice.

10 Qhapaq or Qhapax is the Quechua word for main, rich, powerful. The Qhapax Raymi, or Main Fiesta is celebrated on summer solstice. It is dedicated to the Sun, its complete name being Ohapax Inti Raymi.

11 The Alasitas fair (Feria de Alasitas) is celebrated on January. It is dedicated to Ekeko, the Aymara deity of abundance. The god is given a miniature version of what the worshipper wants to obtain, which is hanged on his body. Images of Ekeko are kept at home, where he is given cigarettes to smoke.

12 The ritual called challa or chaya consists on pouring or sprinkling the ground with drinks to invite the Mother Earth or Pachamama in order to express gratitude and to ask for protection and prosperity. This may be explained as a simplification of other rituals of reciprocity with the Pachamama, in which a hole on the ground is made in order to feed the Mother Earth. Houses, work places, tools, or vehicles can be given a chaya, while in rural zones it is used to promote fertility of animals and crops. 
bands of the immigrant community in a fiesta in honor of Virgin Mary, even if they call themselves indigenous. The Argentine bands search for authenticity in their experience and are more interested in the aesthetic aspects of the performance. In this sense, they value the recreation of the Andean fiesta context, and the religious devotion is a part of this scene:

"I don't come to Charrúa to play to the Virgin. I am an atheist, or better said, an agnostic. I am not looking for my identity, I am an Italian descendant, and that doesn't make me a better or worse person, it wouldn't affect me if I were told I descend from blacks, Jews, or Chinese, I don't care... those divisions have no sense for me. I've chosen the siku because it has value by itself. It has complexities, the styles, the way of playing it. It has tradition, it is a wonderful expression of culture...that I choose now, as I chose others at the time I decided to approach them. This [he refers to the fiesta] is part of the culture, of sharing the cultural environment...” P., Banda de sikuris de IMPA ${ }^{13}$.

Thus, a non-judgmental attitude grounded in cultural relativism is the rationale for not questioning the indigenous participation in the procession. The orthodox Marxist conception of religion is also rejected:

"...whatever they decide is OK for me, these are their beliefs, who am I to question them? I am not there sharing that religious feeling, but sharing that moment... of playing with them, and that they allow me to share without being Bolivian or native, stop questioning, dude, for me everything is OK... I am not coming to infiltrate myself here to tell these people what they should think. Other people do that, for me it's very violent, and I'm not into that..." (M., he played in different bands but was not a stable member of any band at the moment of the interview)

Another informant relates the playing mode and the relationship with the environment, and compares it with the industrial and consumer society:

“...well, I don't need to explain how it [the siku] is played, but I always thought that needing a partner to produce a melody was really [like] being a part of a whole... that's why the [native] communities have another kind of relationship with the earth, with Mother Earth. They know that without harmony with the earth they won't survive, that they are part of a whole. Here, in the city, in this system, each person lives in a Tupperware-sealed box [isolated], nobody knows the name of the neighbor. 'Cause the system promotes it, you are taught since childhood, nobody cares about anything but himself, and this applies to nature too. Note how we sink in this absurd consumerism." L.,

13 IMPA is the Spanish acronym of Metallurgic Industry of Plastic and Aluminum. The bankrupted factory was regained by its workers, and several alternative cultural projects are carried out there today. The band was founded in 2001.

\section{Banda de sikuris Wayramanta.}

Participation in the celebration is not related to the Catholic background of these interviewees. The role of the Church in the submission of the natives is beyond discussion, but the rejection of an orthodox Marxist conceptualization of religion is also present. There is a common ground in this rejection: a critical position against oppression and authoritarianism. Western individualism and consumerism is also criticized, and individualistic education is identified as the cause of social isolation as well as the poor connection with the environment. The way in which the siku is played in the bands is held up as a way to rebuild the lost links between a person and the other. Instead of rejecting religion, they propose another kind of harmonic connection, giving a new sense to the Augustinian re-ligare.

The support that the bands previously described give to the indigenous rights movements, and the affinity with their ideological principles are not sufficient reasons for giving up the traditional Catholic parade. However, a third group of bands does not share this view. For these bands, Catholic religion and rituals are a way of perpetuating the European dominance. Those that hold this radical position adopt two different strategies: while some of them decide not to attend the fiesta at all, others participate and parade, but under certain conditions that distinguish them from those that participate in the traditional way.

Some sikuris' bands are composed of members who have undergone a process that they call "the recovery of our identity". For many migrants, especially those that spent many years in the Andean area, Catholic festivities are part of their cultural inheritance. Having been raised in Catholic families and recognized themselves as Catholics, they had to go through a transformation of personal and social identity in order to develop their indigenous pride. These sikuris, who in the past reproduced the functioning models of their Andean Catholic tradition while playing at the Charrúa fiesta, have been confronted with the Church's suppression of native culture as exposed by the indigenous rights activists. Despite this, these bands value other aspects of the fiesta, such as the opportunities of reinforcing the community's social bonds and, especially, of reaching a massive audience that shares their cultural background and are able to appreciate their work:

"If you don't go there to show up... well, let's say that your ideas aren't worth much, because it doesn't make much sense, really, to play on a stage. I am not interested in playing for the porteños, it's the same thing... for me, I really don't care. I go to play at Charrúa because the people there come from the same place. That has been the idea of Sartañani ${ }^{14}$, that's why we don't talk about any church or religion, we talk about playing there because it's a key venue, a really crucial place to be" (M., born in Bolivia, Ayllu

\footnotetext{
14 In Aymara: let's stand up, let's resist
} 
Sartañani’s member).

The organization of indigenous festivals and their increasing relevance during the last decade have also had an impact on the perception of the fiesta. The sikus bands themselves have developed many alternative celebrations in order to share their experiences and perform for bigger audiences. One of these events is a big meeting of bands called Mathapi Apthapi Tinku (a combination of Aymara and Quecha words meaning "meeting") mentioned in the following fragment of an interview, a year later, by a member of the same band:

"It seems that this year the bands will pay in order to perform at Charrúa. I think we won't go this year; we have the mathapi and it's enough... rest assured, it will be more important than Charrúa someday. Anyway, there is still quite a long time and we have to discuss it, but I'm guessing we won't go" (C., born in Bolivia, Ayllu ${ }^{15}$ Sartañani's member).

All these bands seek is a good opportunity to perform in front of an audience that shares their cultural inheritance and competence. This band member's concern about the fee they would have to pay in order to perform at Charrúa is noteworthy. When there are no sponsors (i.e., the aforementioned pasantes), this is the way in which these events are funded, and the honor and prestige of playing at the Our Lady of Copacabana's fiesta is expected to justify the investment. However, for these bands things have changed to the point of considering not performing there if it is necessary to pay.

Performing at the fiesta brings the bands to the attention of the community of migrants. The eyes of the assistants converge on the chapel, where the image of the Virgin is displayed. A stage is arranged outside the chapel; on the stage, the sacred image is exhibited and an animator together with religious and community representatives welcome the participants and briefly describe their history or salient points about them. This stage is the place where the stands are headed. The corridor where the participant groups parade is also protected by fences, so that the audience members have their backs turned on the small square in front of the church. Nobody notices when a band in the square across the street plays, as has sometimes happened; if the bands want to convey a message, the square is not the right place. Therefore, these bands may resort to other ways of showing their disagreement with Catholic policies:

"For example, in recent years when Sartañani performed, the band didn't stop in front of the stage [as the other participants do]. Not only didn't they stop; they turned their backs on the church. They passed

\footnotetext{
15 Ayllu is the traditional community, an Andean native community traditionally linked to a patrilineal extended family. Today, especially in urban contexts, the concept is not related to kinship.
}

walking backwards, because the band's interest isn't to be there because of them [i.e., the Catholic community], it is because of the people that suffer from something like the concealment of their identity. I noticed many other people that are... that are very proud of it [their indigenous identity]. (M., born in Bolivia, Ayllu Sartañani`s member).

\subsection{Religiosity Outside of Charrúa}

As mentioned above, there are bands whose members agree to relinquish the celebration. Although their profiles are not homogeneous, many of them belong to Indianist movements or are activists of social movements for indigenous rights. They have typically been in contact with people and political ideas outside the migrants' community for a lengthy period of time. All of them believe that belonging to the Catholic religion is a way of perpetuating the history of European dominance. This background laid the foundation for their decision to stand aside from the festival of Charrúa, even though they are aware of its relevance for the migrants. One of my informants explained that:

"...actually, more than anything else, it has to do with an ideology issue and, let's say, related to coherence. If you think and realize what history is [he refers to historical facts], the Virgin, God, are part of the oppression and the subjugation of the peoples. So today, from [the point of view of] our culture and philosophy, we cannot go and play our music for her [the Virgin] ... even though, many go [to play there]" (P., Sikuris del Arco Iris).

The decision does not imply that they have lost or renounced beliefs related to the sacred. Re-signifying and relabeling such beliefs as "spirituality," they combine perspectives, adapt concepts and practices from different sources that are claimed as autochthonous, and establish a strong dichotomy between pre-Hispanic and Catholic religiosities.

"In the past, spirituality was a complement of our culture. Spirituality is a complement of life. Why do I say this? I'll give you an example: on a New Year's Day, or on a Day of the Pacha ${ }^{16}$, perhaps we are [gathered] around the fire and [celebrating] with a lot of things, and that is something harmonic that we did over the course of thousands of years, didn't we? When we did all these things, it didn't end there. This brother would continue working the land, would continue observing the stars and how the cosmos was, he would continue doing other things, but the spiritual part was a complement of culture. Hence we, here, as natives, have to understand the same: spirituality is a complement... they [the pre-Hispanic natives] believed

16 Pacha is used as a shortened word for Pachamama. One of the meanings of the Quechua word Pacha is "world" or "Earth". 
in Nature, the sun, the water, they believe in natural things, and here, the Church is spreading among us the belief in an almighty god" (E., born in Jujuy, Argentina, Sikuris del Arco Iris).

One difference that is highlighted is the idea that natives were in harmony with nature and that their deities were benevolent natural forces with which they lived integrated in a complementary order, while the Catholic God is separated from humans and from nature and has a will and unlimited power. In the present, this deity would be still imposed on natives -and this ongoing subjugation to the deity is the one that, in turn, Western civilization imposes on nature:

"Nowadays I understand what he, my dad, told me, and for me that [what he said] didn't make sense. He was at the mine Aguilar [as a worker], and when he talked against the mine, the mining method, because they were blowing up the mine, they were blowing up the Earth, that was a way of blowing up ourselves. It's like somebody that is blowing up his mother. This was what he told us. Because the Pacha is the producer of everything, everything that can exist on it. And we are part of that, because if we don't have our Earth we cannot do anything at all". (E., born in Jujuy, Argentina, Sikuris del Arco Iris).

“...because modern societies don't feel we are part of a whole, it's all about domination and exploitation. That is the relationship; it is defined by how much they can obtain. The natives and their relationship with the Pacha is completely different. Even though everything was spoiled by capitalism, you can see it when you observe, for instance, the rituals. You can see the difference: they venerate the Earth." (A., born in Buenos Aires, he belonged to various bands in the past).

As analyzed by Bonfil Batalla [15], the indigenous peoples' political movements in Hispanic-America posed a binary opposition between Western and native societies. Bonfil Batalla characterized the common ground that he found in all indigenous peoples' discourses as a philosophical and ideological unity. He took the ideas of the Bolivian native philosopher and political leader Fausto Reinaga as a reference point for defining a native Andean ideology. Here "Indigenous" or "Amautic ${ }^{17}$ thought" was opposed to the "Socratic thought" held to be characteristic of Western ideologies. Although Bonfil Batalla's analysis can be reductionist, and seemed a bit forced at that time, the processes of globalization that took place during the 1990s contributed to the development and wider relevance of his ideas. One of the central aspects of this construction is the opposition between the attitude of balance and living in

17 The amautas are the wise men of the indigenous communities. They have great moral authority and the natives seek their advice, they act also as political counselors. During the Inca Empire, they were the teachers of the Inca's descendants. harmony with nature that characterizes native ideologies, and the domineering and imbalanced attitude toward the environment that tends to characterize capitalism. The Act of Reconstitution of the Aymara-Quichwa Nation (2001), sheds light on this process and its links with indigenous religiosity:

“...we are inhabitants of this territory called Qullasuyu. We have been born with deep roots in this American continent, from the fecund womb of our Pachamama. With great respect and harmony with nature, our ancestors have developed our own life philosophy, our science and technology, our spirituality. During millennia we cultivated life in abundance, without exploiting or damaging nature...,"18

In the present, their ideology has appropriated modern ecological ideas and concepts, which in turn have contributed to the growth of their new religiosity. The social representations of the Pachamama can also be related to scientific knowledge transmitted through the Argentine educational system, as the following example illustrates:

"Pachamama is everything, we are all Pachamama. Every creature on Earth, or in the universe, is part of the Pachamama, is part of a cosmic balance. Because when you analyze what we are... we are soil, water, microorganisms, bacteria, we're made of the same stuff of which a plant is made, an animal is made, all the things on Earth are made of the same stuff. That's it. We only have a different aspect, because we are humans..." (E., born in Jujuy, Argentina, Sikuris del Arco Iris).

The social organization that the actors attribute to the pre-Hispanic communities, based on reciprocity and complementarity among their members and among communities, is also associated to the harmonic relationship with nature. This Sumaj Causay (in Quechua) or Suma Qamaña (in Aymara) ${ }^{19}$-the Good Way of Living- is reflected in the complementary performance of the sikus, dialogued and dualistic performing mode described by Valencia Chacón [4-16] and Sánchez Canedo [17], among others. The parallelism, between sikus' music and society, which was first formulated by Valencia Chacón, emerges in the narrative of many sikus' bands, particularly among those that are ideologically closer to the indigenous rights' movements [5].

“...you see, there [at the sikus' bands], let's say, there is arka-ira, that's to say there is something

18 “...somos habitantes milenarios de este territorio llamado Qullasuyu, hemos nacido a la vida con raíces profundas en este continente americano, del vientre fecundo de nuestra Pachamama [...] Con mucho respeto y en armonía con la naturaleza nuestros ancestros han desarrollado nuestra propia filosofía de vida, nuestra ciencia y tecnología, nuestra espiritualidad. Durante milenios hemos sabido cultivar la vida en abundancia, sin explotar ni dañar a la naturaleza. (Acta de Reconstitución de la Nación Aymara-Qhichwa. Manifiesto de Jach'ak'achi, 2001).

19 The Buen Vivir, Sumaj Kawsay/Sumaj Causay or Suma Qamaña (Good Way of Living) has been included on the new Constitutions of Ecuador (2008) and Bolivia (2009). 
complementary, this is dualism, there are chulis, there are maltas and there are sankhas ${ }^{20}$, the children, the adults and the elderly, arka and ira that are male and female, which is duality... your partner, female or male, somebody who is next to you, the one who complements you, to answer you and to listen to you, that's why the siku is divided in halves..." (E., born in Jujuy, Argentina, Sikuris del Arco Iris).

“...'cause for the natives, everything is arranged in halves, it is a dualistic worldview, even the architecture shows it, if you analyze the ancient cities. Night and day, dry/wet, East/West... Inti/ Pacha, everything, and everything has its opposite, without confronting, that's not native, so you have God, for the Europeans, the opposite... what is the opposite? The devil, but the devil is evil, it's bad and it must be destroyed, that is not dualistic, d' you see?" N., professional musician and founder and trainer of different bands, born in Bolivia.

Further discussion of the dualistic worldview of the Andean natives, a topic that has been documented and explored by many anthropologists and archeologists, lies outside the scope of this article. Anyway, the urban sikuris relate the complementary dualism of the native worldview with their musical practices, and attempt to reproduce through these practices (both musically and in terms of social organization) the way in which indigenous communities work. Thus, they promote the participation of all the members of the band in decision-making processes and these responsibilities are shared among them, regardless of their expertise as players. In this sense, the bands attempt to reproduce the sumaj causay or suma qamaña, and boost reciprocity among their members and among different bands, such as the ayni system, a traditional reciprocal exchange of goods and services that they use to raise funds to cover the expenditures of each band [5].

Nevertheless, and regardless of the strategies that each sikus band adopts with respect to the festivity of Our Lady of Copacabana at Charrúa, on different occasions, they all perform rituals to the Pachamama, as described on the following paragraphs.

\subsection{The Pachamama and the Sikuris' Bands: Continuity and Change}

As previously mentioned, some pre-Hispanic rituals are still alive, and coexist with Catholic ones, even among the most devout Christian followers. All the native rituals, from small familial ones to those involving the whole community, include a tribute to the Pachamama. These rituals may have different purposes. Some are requests for protection, permission, or prosperity, while others are simply expressions of thanks for the gifts of the Pachamama. These

20 Chuli, malta and sankha are sikus with different registers that comprise the tropa or set which is most used in Buenos Aires. For more detailed information on the kinds of tropas see Uribe Taboada [6]. objectives may also be combined within the same ritual. The rituals to the Pachamama can, in turn, be a part of a bigger celebration, as in the case of the native New Year or Inti Raymi, the summer solstice, or Qhapaq Raymi, which is also linked to the sprouting of the corn, or the Pachamama's Day (on August, $1^{\text {st }}$ ). Other collective ceremonies are also performed in rural native communities. The ceremonies marking familial and more intimate occasions, such as rutichico or first haircut, can include urban customs or even Catholic rites; here too there is often a tribute to the Pachamama. Even other events important to the sikus bands, such as the first use of a new set of instruments, can be celebrated with a ritual that includes the Pachamama. If a member of the band starts a new project or work activity, a ritual invoking the protection and prosperity of the Pachamama on behalf of the tools and/or working place is often conducted. At an individual level, the Pachamama is offered alcoholic drinks whenever a party or meeting takes place by dropping a little beverage on the floor when the glass is full: each drinker "invites" the Pachamama to drink and shares what he or she has received. This symbolic and intimate gesture of reciprocity with the Pachamama is explained as "convidar a la Pacha" (offering -a drink- to the Pachamama).

Large complex rituals involve more formal procedures of worshipping the Pachamama. Beyond the explanations about the Pachamama, in which the deity is portrayed as an abstract wholeness, the representations that appear in the ritual performances are completely different: the Pachamama must be fed and given spirituous beverages. She repays what she is offered and likes to be respected and praised. This animistic conception of the Pachamama, traditional in rural areas, is a basic foundation of the rituals.

In the northwestern region of Argentina, the ritual of feeding the Pachamama is known as corpachada. The sikuris of Buenos Aires explain the rites with the same phrase: "darle de comer a la tierra", or feed the Earth. The participants gather in parks that are important for them usually because of historical events or because they are places where the migrant community usually meets - with coca leaves, and the food and the drinks they will offer. The ritual, usually led by a couple, consists in opening a hole in the ground. This process is called "abrir la boca de la tierra", or opening the mouth of the Earth. The food for the deity is placed around the hole, or arranged on a colored piece of woven cloth, called Aguayo, resembling a table; in certain Bolivian regions it is called mesa, the Spanish word for table. A ritual fire is lit into the hole, to burn aromatic herbs and connect the earth to the sky through the smoke. After the leaders pray in turns, then the drinks are poured into the hole, the coca leaves and the food are also thrown, and then the hole is closed. The participants share the ritual food and drinks. Sometimes the participants, who witness the actions around the hole, hold hands to end the ceremony, play their sikus and move in their typical circular choreography.

This ritual may have variants depending on the preference of the band members, but it never includes the wilancha, a 
ritual sacrifice of an animal, usually a llama, that takes place in rural communities in Bolivia and Peru. In many cases, especially among sikuris that were born in Buenos Aires, the rite does not have any religious or spiritual connotations, being just another occasion to meet and play with the band.

The representations of the Pachamama have undergone many changes, some of which emerge in the rituals. Some features can be attributed to the influence of the New Age; others are related to the changes that the representations of the sacred have undergone in the Catholic doctrine and rites, such as the rejection of the idea of a punishing and menacing deity, which is not acceptable for a modern urban citizen. Some notions of the Pachamama associated with traditional aspects can be found in the rituals performed in August, the month dedicated to the Pachamama, when people ask her for protection and prosperity.

There is a popular saying in northwestern Argentina that is recited during the Pachamama celebration of August: "Pachamama, santa tierra, no me comas, todavía soy joven y puedo dejar semilla" (Pachamama, holy earth, do not eat me, I am still young and can leave my seeds). These words cannot be understood without analyzing the context: August is considered a dangerous time in this region, as it is the second half of the winter. Many respiratory diseases that start in winter are fatal to elderly or weakened people, especially in rural areas where medical treatment is not easily accessible. That is the reason why another popular saying in all rural areas of Argentina is: "si paso Agosto soy salvo" (if I overcome August, I am safe). That is, the speaker who has been able to survive the dangers of August will continue to live into the succeeding seasons. In these areas, it is common to make amulets that are worn as protections in August, together with some alcoholic liquors made with rue ${ }^{21}$ that are drunk in August to avoid death or, in other words, to avoid being taken for the Pachamama. The inhabitants of these regions are both grateful and fearful of the deity, so asking for her protection, wearing amulets or drinking protective tonics are countermeasures against the damage that the Pachamama can inflict on people. The Pachamama can also provoke illnesses or even death as a result of a religious-ritual imbalance [18], as in the case of the traditional illness called "agarradura" 22 . However, the rituals for the Pachamama in August always include gratitude, expressed through the words of their leaders. The participants show their appreciation for being alive, something that is possible because the deity has given them the material resources: the land, the water, the plants, the

21 The rue (Ruta graveolens and Ruta chalepensis are the species used in Argentina) is a plant of extended use both in sorcery and traditional medicine.

22 According to the natives, agarradura may be caused by the Pachamama: the deity grabs the soul of a person and he or she gradually loses strength and energy. This happens when the person stays in a spot that is considered taboo or if the offerings to the deity are not observed. animals and the minerals. They offer the fruits of their labor, feed the Pachamama, and offer her the things she likes most. In this act of reciprocity, they also ask her to grant them a new period of prosperity.

The ambivalence of the Pachamama in rural areas becomes evident through the rituals: the Pachamama makes the life of the participants possible by sharing her natural resources (or giving herself to the people), but she may also be dangerous and demand the lives of the ones that break taboos -for example, passing through forbidden places without asking her permission- and may also require the blood of a sacrificed animal at the wilancha.

On the contrary, the rituals for the Pachamama in Buenos Aires show only her positive aspects, and the deity is considered the nourishing mother who protects and is generous toward all. While she offers natural resources as gifts, natural catastrophes stem not from her ill will, but rather from the avarice of human beings, or from capitalism and consumerism that provoke over-exploitation, depletion of resources and pollution, the antithesis of the native Good Way of Life:

"The Pacha is the origin, the creator of everything; she generates everything on her. And we are a part of that; if we don't have the Pacha we don't exist. She gives us everything, but despite this, we hurt her. We destroy everything, capitalism destroy everything. Even many brothers got crazy with this insane model of uncontrolled consumerism. That's why we say that our choice is the Sumaj Causay, to protect the Earth, to protect ourselves, to protect our mother". P., banda Wayna Marka.

The Pachamama is also related to the single lexemes that compose the word. I have found this explanation only in Buenos Aires; it is an extended concept supported by Indianistas. This conceptualization integrates the different meanings of the word "Pacha"; the noun (world, our planet, universe, place, and time), the adjective (same) and the preposition (from, indicating origin or place) [19-20]. While the activists of indigenous movements have developed this bi-dimensional time/space meaning, people in rural areas just refer to the Pachamama as the Mother earth.

“...actually, Pacha means world, time, and space. It is not only the Earth, it's the whole universe... the sun, the stars, the trees, the wind... the whole cosmos... the world that we pollute $[\ldots]$ and there are many people that are now awakening to the consciousness... this happens through intuition. They begin to realize that there are many other things... that in many occasions we don't listen, we are always with the visual [employing the visual sense], and this comes more from reason, we have to learn to listen to our heart... that energy, the messages we receive... the things that happen to us... we don't give significance to that..." A., born in Jujuy, Sikuris del Arco Iris.

The influence of New Age spirituality on the indigenous movements is noteworthy and interesting. They appropriate some core concepts, such as energy, the importance of 
connecting with the inner self, and the criticism of positivism, and integrate them into a coherent discourse adapted to the present. Through this process of appropriation, these concepts become integral parts of their identity, giving Indianism a position of significant influence within the counter-hegemonic movements.

However, when seen in its religious context, the ritual of the Pachamama in Buenos Aires cannot simply be reduced to an expression of identity politics or the reinforcement of an ideological position; rather, the Pachamama is also evoked by emotive words full of lyricism:

"...Who is the woman that gives everything without receiving anything in return, the one that gives you love through the Wayra's ${ }^{23}$ embrace? Who is the woman that fills your paths with colors, that gives you colored flowers so that your day is full of love and joy? Who is the woman that lets the birds live on her hair, and waits until one day they fly away to reach the sky, leaving their feelings with her? Who is the woman who feeds me with her flesh, whose bones I use to build my home? That woman is the Pachamama. She let me draw mountains with her body, let me create my ceramics... and when Inti does not illuminate my days, she will cuddle me in her flesh and I will be, again, Pachamama”, A., born in Jujuy, Sikuris del Arco Iris

The contrast between the Catholic deity and the Pachamama is explained by another member of the same band, which does not participate of the Catholic festivity. Ideas of wholeness, balance and equality are presented again here, as the interviewee talks about native spirituality:

"We don't believe in God because we don't believe in someone that created the life of the whole world. We are part of a cosmic balance, and we are nature. We are all equals, nobody is superior to anyone, not even to a drop of water, not even to a sand grain. We are all equals. The sun, the moon, everything that exists is necessary for that cosmic balance" (E., born in Jujuy, Argentina, Sikuris del Arco Iris).

\section{Conclusions}

In Buenos Aires, the massive participation of the sikus bands in the Catholic fiesta of Our Lady of Copacabana, patron saint of Bolivia, has undergone a decline; in the present, the quantity of bands and sikuris continues to diminish year after year. On the contrary, in the small cities and towns of the Andean region, the traditional participation of sikus' bands in Catholic celebrations remains steady or has increased.

The decisions of the bands with regard to both participation and mode of performance express processes

23 Wayra is the Quechua word for wind. intrinsic to the life experiences of social actors in the diverse environment of a big city; the changes they enact go beyond the strictly religious realm and are strongly related to an identity quest, which many define as an "identity recovery". This process of re-ethnicization is a deliberate attempt to recover and rebuild the culture that they believe truly belongs to them as natives, insofar as it precedes the Spanish conquest. In this context, the $s i k u$, its complementary mode of performance, and the religious beliefs systems -both Catholicism and "indigenous spirituality"- have specific meanings and relevance. In this arena of public performance, the agency and autonomy of indigenous actors is validated and legitimized by porteños that question a construction of national identity derived from European heritage and policies. The multi-cultural counter-hegemonic ideology is the common ground where Indianistas, New Age followers and anti-establishment activists overlap, a space of promotion of spirituality that is beyond the limits of institutionalized religion. However, the diversity of the responses to the new opportunities and challenges that the new context provides correlate with the heterogeneity of the sikuris regarding their precedence and their life experience.

Taking into account the relevance of the fiesta for the articulation of social life among the Bolivian migrants, some bands have created alternative spaces within which they can maintain their presence at the celebration, choosing to perform in the square in front of the chapel, but not to parade in front of the Virgin. By using this (not quite successful) strategy, they try to maintain the bonds with the community while at the same time avoiding any symbolic gesture of devotion to a religious figure associated with colonial dominance and acculturation, as well as with the continuing inequality between the indigenous and white European population.

A more effective and visible strategy to mediate the conflict inherent in being an Indianista and at the same time parading for a Catholic saint is the semiotic use of the body during the performances to convey meaning. In this way, the band takes part in the community celebration, appropriating a socialized -and sacred- space and staging their artistic production for the audience, while ignoring Catholicism by turning their backs on the Virgin image and the church. In other words, they take part in the social event, but not in the religious one.

Other bands participate at the event in the traditional way. Without ignoring the use that the Europeans made of the religion, they live the fiesta as a part of their Andean cultural heritage, as the indigenous people do in the communities where they come from, places in which the Virgin has been appropriated since the times of Tito Yupanqui, the native sculptor of the patron saint image. The festival is an essential part of their lives, because they are worshippers of the Virgin, whom they honor with the music of their indigenous sikus.

However, it is important to recognize that a lowered, or modified and critical level of participation in the religious aspects of the festival does not necessarily imply a loss of religiosity. The celebration of rituals of pre-Hispanic roots, 
although reshaped by the re-ethnicization processes, and strongly influenced by New Age ideas, have proliferated recently. Some concepts such as energy and harmony -a core concept used to explain the Good Way of Life- or that of equality among every creature or object that comprise the Pacha, are not traditional.

The polysemy and complexity regarding the word Pacha both in Quechua and Aymara (although the Aymara word is less complex than the Quechua term) makes the translation highly context-dependent. As a noun, pacha means place, world, space, but also time. However, the lexical units and compound words that include the root pacha that can be found in the dictionaries I consulted suggest that a single concept such as "space-time" is not traditional. For the natives that live in rural areas, Pachamama is the Mother Earth, which they explain as a compound word formed by pacha, Earth and mama, mother. As a preposition pacha means "from", indicating procedence, but cannot be translated as "origin". According to the chronicles of indigenous historians from late sixteenth and seventeenth centuries, Juan de Dios Pachacuti Yampi [21] and Felipe Huamán Poma de Ayala [22], the world was created by the god Thunupa or Wiracocha (Wiraxuxha) after emerging from the Lake Titicaca. For his part, Garcilaso de la Vega [7] described the founding myth of the Inca Empire by the siblings Manco Capac and Mama Ocllo, who were sent by their father Inti to humankind. These ancient myths are not compatible with the idea of the Pacha as origin of everything.

The discourses of the sikuris in Buenos Aires develop concepts such as energy, equality among animated and unanimated beings living in harmony with nature, and portray the Pachamama as a single, all-encompassing wholeness which is the origin of all that exists, and in which everybody and everything are connected in balance. These positive notions coexist with the obligation to feed and offer libations to the Pachamama in order to secure her protection and avoid damage and/or illness. But nobody in the city refers to the ambivalence of the Pachamama, an aspect openly acknowledged in rural communities. Thus, due to the influence of Westernized beliefs and ideologies such as New Age spirituality and ecologism, the Pachamama has gained a benevolent profile in the urban context.

However, although institutionalized religions, particularly Catholicism, have lost influence, followers and prestige among youngsters in Buenos Aires, religious quest, now refigured under the rubric of spirituality, accompanies the sikuris of Buenos Aires, who articulate, in relation to this concept, demands that belong to the political, economic and cultural realms.

\section{REFERENCES}

[1] C. Bolaños. La música en el Antiguo Perú. La música en el
Perú. Patronato Popular y Porvenir Pro Música Clásica, Lima, 1985, 4-64.

[2] C. Mansilla Vásquez. El artefacto sonoro más antiguo del Perú: aclaración de un dato histórico. Revista Española de Antropología Americana, Vol. 39, No. 1, 1-9.

[3] C. Vega. Panorama de la música popular argentina. INMCV, Buenos Aires, 2010 [1944].

[4] A. Valencia Chacón. Jjaktasiña Irampi Arcampi. El Diálogo Musical: Técnica del Siku Bipolar. Boletín de Lima, Año 4, No. 22, 8-21.

[5] A. Vega. Estamos en Ayni; sikuris, música y narrativas. XX Jornadas Nacionales de Folklore. Buenos Aires, November, 9-10, 2011.

[6] E. Uribe Taboada. Precisiones en torno al siku. Online available from http://www.sikurinutapa.co.cc/precisiones-en-torno-al- siku/

[7] G. de la Vega. Comentarios Reales de los Incas. C Araníbar Ed. México, FCE, 1991 [1609].

[8] I. Aretz Thiele. Música Tradicional Argentina. Tucumán. Historia y Folklore. Universidad Nacional de Tucumán, Buenos Aires, 1946.

[9] A. Maguid. Migrantes limítrofes en el mercado del trabajo del Área Metropolitana de Buenos Aires, 1980-1996. Estudios Migratorios Latinoamericanos, No. 35, 31-62.

[10] J. Dandler and C. Medeiros. Temporary migration from Cochabamba, Bolivia, to Argentina: patterns and impact in sending areas". When borders don't divide: labor migration and refugee movements in the Americas. P. Pessar (ed.). Center for Migration Studies, New York, 1988, 8-41.

[11] S. M. Sassone, y J. Hughes. Fe, devoción y espacio público: cuando los migrantes construyen lugares. Cultura, territorios y prácticas religiosas. C. T. Carballo, (comp.). Prometeo Libros, Buenos Aires, 2009, 151-174.

[12] T. H. Abercrombie. Pathways of memory and power. Ethnography and history among an Andean people, University of Wisconsin Press, Madison, 1998.

[13] M. Carozzi. Ready to move along. The sacralisation of disembedding in the New Age Movement and The Alternative Circuit in Buenos Aires. Civilizations No. 51, 139-154.

[14] M. del R. Contepomi. La Nueva Era en Misiones. El Color Local de un Movimiento Global. Estudios Regionales No 17. 141-161.

[15] G. Bonfil Batalla. Utopía y revolución. El pensamiento político contemporáneo de los indios en América Latina. G. Bonfil (comp.), Utopía y revolución. Editorial Nueva Imagen, México, 1981, 11-59.

[16] A. Valencia Chacón. Américo 1982b El Siku Bipolar en el Antiguo Perú. Boletín de Lima, Año 4, No. 23, 29-48.

[17] W. Sánchez Canedo. Algunas consideraciones hipotéticas sobre música y sistema de pensamiento. La flauta de pan en los Andes bolivianos. Cosmología y música en los Andes, M. Bauman (ed.). Iberoamericana, Madrid, 1996, 83-105.

[18] A. Idoyaga Molina. Natural and Mythical explanations. Reflections on the taxonomies of disease in North-Western Argentina (NWA)", Acta Americana, Vol. 8, No.1, 2000, 
$17-32$.

[19] J. Lira. Diccionario Kkeqhuwa-Español. Universidad Nacional de Tucumán, Tucumán, 1944.

[20] Diccionario Quechua-Aymara al español. Online available from: http://www.katari.org/diccionario/diccionario.php.
[21] Pachacuti Yamqui Salcamaygua, Juan de Santa Cruz. Relación de edades deste reyno del Piru. Institut Francais D'Études Andines- Centro de Estudios Regionales Andinos "Bartolomé de Las Casas", Cusco, 1993.

[22] F. Guamán. Poma de Ayala. Nueva crónica y buen gobierno. J. Murra, R. Adorno \& J. L. Urioste (eds.). Siglo XXI, México, 1987. 